\title{
Molecular cloning, overexpression, purification, and sequence analysis of the giant panda (Ailuropoda melanoleuca) ferritin light polypeptide
}

L. Fu' ${ }^{1}$, Y.L. Hou ${ }^{1}$, X. Ding ${ }^{1}$, Y.J. Du ${ }^{2}$, H.Q. Zhu ${ }^{1}$, N. Zhang ${ }^{1}$ and W.R. Hou ${ }^{1}$

${ }^{1}$ Key Laboratory of Southwest China Wildlife Resources Conservation (Ministry of Education), College of Life Sciences, China West Normal University, Nanchong, Sichuan Province, China

${ }^{2}$ Biochemical Department,

Basic Education College of Zhanjiang Normal University, Zhanjiang, China

Corresponding author: W.R. Hou

E-mail: hwr@cwnu.edu.cn

Genet. Mol. Res. 15 (3): gmr.15038593

Received March 1, 2016

Accepted July 21, 2016

Published August 30, 2016

DOI http://dx.doi.org/10.4238/gmr.15038593

Copyright (C) 2016 The Authors. This is an open-access article distributed under the terms of the Creative Commons Attribution ShareAlike (CC BY-SA) 4.0 License.

ABSTRACT. The complementary DNA (cDNA) of the giant panda (Ailuropoda melanoleuca) ferritin light polypeptide (FTL) gene was successfully cloned using reverse transcription-polymerase chain reaction technology. We constructed a recombinant expression vector containing FTL cDNA and overexpressed it in Escherichia coli using pET28a plasmids. The expressed protein was then purified by nickel chelate affinity chromatography. The cloned cDNA fragment was $580 \mathrm{bp}$ long and contained an open reading frame of $525 \mathrm{bp}$. The deduced protein sequence was composed of 175 amino acids and had an estimated molecular weight of $19.90 \mathrm{kDa}$, with an isoelectric 
point of 5.53. Topology prediction revealed one N-glycosylation site, two casein kinase II phosphorylation sites, one N-myristoylation site, two protein kinase $\mathrm{C}$ phosphorylation sites, and one cell attachment sequence. Alignment indicated that the nucleotide and deduced amino acid sequences are highly conserved across several mammals, including Homo sapiens, Cavia porcellus, Equus caballus, and Felis catus, among others. The FTL gene was readily expressed in E. coli, which gave rise to the accumulation of a polypeptide of the expected size $(25.50 \mathrm{kDa}$, including an $\mathrm{N}$-terminal polyhistidine tag).

Key words: Giant panda; Ferritin; cDNA; Overexpression; Purification

\section{INTRODUCTION}

Ferritin light polypeptide (FTL), encoded by the FTL gene, is the light subunit of ferritin, a highly conserved protein with multiple functions that is ubiquitously expressed in a variety of organisms. Ferritin is composed of 24 subunits of heavy and light chains, and is responsible for intracellular storage of the iron required for normal cell growth and proliferation. However, excessive iron is potentially harmful, since it can catalyze the formation of toxic reactive oxygen species via the Fenton reaction (Connor et al., 2001; Salvador, 2010). In this respect, ferritin has been shown to protect cells against oxidative damage by modulating iron homeostasis, and is also involved in immunity (Goto et al., 1999; Stites et al., 1999; Zhang et al., 2013). Previous studies have demonstrated an association between oxidative damage of DNA and carcinogenesis. Therefore, greater attention has been paid to the relationship between ferritin and cancer (Ricolleau et al., 2006). Mammalian ferritins are usually composed of 24 subunits of two different types, known as the light $(\mathrm{L})$ and heavy $(\mathrm{H})$ chains, which share $55 \%$ amino acid sequence identity. The ferritin $\mathrm{H}$ subunit demonstrates potent ferroxidase activity that catalyzes the oxidation of ferrous iron, whereas $\mathrm{L}$ ferritin plays a role in iron nucleation and protein stability (Park et al., 2002; Arosio et al., 2009). Given the close relationship between the ferritin $\mathrm{H}$ chain and tumorigenesis (Ferreira et al., 2000), it remains to be clarified whether the L chain, consisting of a similar amino acid sequence, exhibits a comparable function. Defects in the FTL gene, of which there exist multiple pseudogenes, are associated with several neurodegenerative diseases and hyperferritinemia-cataract syndrome (Cheepsunthorn et al., 1998; Cao et al., 2010).

The giant panda (Ailuropoda melanoleuca), one of the oldest and rarest mammals, is known as the "national treasure of China", the only country in which it is currently found. It is counted among the world's most endangered species (Cazzola et al., 1997; Wang et al., 2015). Over recent years, conservation measures have been put in place and scientists have realized tremendous success in areas such as breeding, ecology, and propagation, among others. Meanwhile, giant panda research and conservation has been increasingly focusing on the level of gene functionality, which is currently drawing much attention in this field (Allerson et al., 1999; Liao et al., 2003; Hou et al., 2012; Hou et al., 2013; Wang et al., 2015; Wang et al., 2016). In this study, we designed primers based on the available FTL gene sequences of several mammalian species, including Homo sapiens, Cavia porcellus, Equus caballus, and Felis catus, and used reverse transcriptase-polymerase chain reaction (RT-PCR) to amplify FTL complementary DNA (cDNA) from total RNA isolated from giant panda skeletal muscle.

Genetics and Molecular Research 15 (3): gmr.15038593 
We then analyzed the protein sequence inferred from the cDNA and compared it with other FTL sequences reported from humans and other animals. We also constructed a recombinant expression vector containing FTL cDNA, which we overexpressed in Escherichia coli using pET28a plasmids. Under optimized expression conditions, we successfully obtained large amounts of recombinant giant panda FTL protein for the first time. The availability of FTL sequences from other animals in GenBank allowed us to test the potential utility of this gene in phylogenetic analysis.

\section{MATERIAL AND METHODS}

\section{Materials}

Skeletal muscle was collected from a giant panda that had expired of natural causes at the Wolong Conservation Center of the Giant Panda (Sichuan, China). The collected skeletal muscle was frozen in liquid nitrogen and used for RNA isolation. RT kits were purchased from Promega (Beijing, China); Total Tissue/Cell RNA Extraction Kits from Waton Inc. (Shanghai, China); Gel Extraction Mini Kits from OMEGA Corporation (Kanpur, India); the pMD18-T Vector System and restriction enzymes EcoRI and HindIII from TaKaRa Bio Group (Dalian, China); and DNA polymerases from Sangon Co. (Shanghai, China). E. coli DH5 $\alpha$ host bacteria were stored in our laboratory (Key Laboratory of Southwest China Wildlife Resources Conservation, Nanchong, China).

\section{DNA and RNA isolation}

Phenylmethylsulfonyl fluoride $(0.1 \mathrm{mg} / \mathrm{mL})$ was used as an RNase inhibitor in the following procedure. Muscle tissue $(500 \mathrm{mg}$ ) was ground to a powder in liquid nitrogen and completely suspended in $15 \mathrm{~mL}$ lysis buffer, consisting of $10 \mathrm{mM}$ Tris- $\mathrm{HCl}, \mathrm{pH} \mathrm{8.0,100}$ $\mathrm{mM}$ ethylenediaminetetraacetic acid (EDTA), and $0.5 \%$ sodium dodecyl sulfate (SDS). After treatment with proteinase $\mathrm{K}\left(100 \mathrm{mg} / \mathrm{mL}\right.$, final concentration) for $3 \mathrm{~h}$ at $55^{\circ} \mathrm{C}$, the mixture was then cooled to room temperature and mixed with water-saturated phenol, $\mathrm{pH} 8$, before being centrifuged at $5000 \mathrm{~g}$ for $20 \mathrm{~min}$ at $4^{\circ} \mathrm{C}$. Supernatants were then pooled, mixed with an equal volume of 1:1 phenol:chloroform $(\mathrm{v} / \mathrm{v})$, and centrifuged. The supernatant was subsequently collected, from which DNA was then precipitated using $70 \%$ ethanol. The obtained DNA was dissolved in Tris-EDTA buffer and stored at $-20^{\circ} \mathrm{C}$. Total RNA was isolated from approximately $400 \mathrm{mg}$ muscle tissue using Total Tissue/Cell RNA Extraction Kits, dissolved in diethyl pyrocarbonate-treated water, and kept at $-70^{\circ} \mathrm{C}$ (Du et al., 2007; Nutting et al., 2008).

\section{Primer design and RT-PCR}

PCR primers were designed using Primer Premier 5.0 (PREMIER Biosoft, Palo Alto, CA, USA), based on FTL mRNA sequences from H. sapiens (accession No. NM_000146), $C$. porcellus (NM_001172858), Canis lupus familiaris (NC_006583), Bos taurus ( $\overline{\mathrm{NC}}$ _007316), Macaca fascicularis (NC_022290), Oryctolagus cuniculus (NW_003159655), E. caballus (NM_001114540), F. catus (NM_001048150), and Sus scrofa (NC_010448). The primers used for amplification of FTL cDNA were as follows: FTL-F, 5'-TTCGAGCTTACCTCTTAAT-3'; and $F T L-$ R, 5'-GCTGCTGGGCTCCAGAGGCTC-3'.

Genetics and Molecular Research 15 (3): gmr.15038593 
The GeneMark Two-Step AMV RT-PCR Kit (Promega) contains all the components required to perform first-strand cDNA synthesis and second-strand DNA amplification. Firststrand cDNA was synthesized from total RNA using oligo(dT) primers in a $20-\mu \mathrm{L}$ reaction containing $0.5 \mathrm{mg}$ Oligo $(\mathrm{dT})_{15}, 1 \mathrm{mg}$ total RNA, $1 \mathrm{mM}$ deoxynucleotide triphosphates (dNTPs), $5 \mathrm{mM} \mathrm{MgCl}, 10 \mathrm{U} / \mathrm{mL}$ RNase inhibitor, and $15 \mathrm{U}$ avian myeloblastosis virus reverse transcriptase, which was incubated for $60 \mathrm{~min}$ at $42^{\circ} \mathrm{C}$. DNA amplification was carried out in a reaction volume of $25 \mu \mathrm{L}$, using the first-strand cDNA as a template. Reaction mixtures contained $200 \mu \mathrm{M}$ each of dGTP, dCTP, dATP, and dTTP (Omega, Shanghai, China), 1.5 $\mathrm{mM} \mathrm{MgCl}, 5 \mathrm{U}$ Taq Plus DNA polymerase (Sangon Co.; Tolar and Neglia, 2003), and 0.3 $\mu \mathrm{M}$ each primer. DNA amplification was performed using an MJ Research (Watertown, MA, USA) PTC-200 thermocycler running the following program: $94^{\circ} \mathrm{C}$ for $4 \mathrm{~min}$, followed by 30 cycles of $94^{\circ} \mathrm{C}$ for $1 \mathrm{~min}, 48^{\circ} \mathrm{C}$ for $0.5 \mathrm{~min}$, and $72^{\circ} \mathrm{C}$ for $1.5 \mathrm{~min}$, before a final extension at $72^{\circ} \mathrm{C}$ for $10 \mathrm{~min}$ (McLeod et al., 2002; Álvarez-Coca-González et al., 2010). PCR products were separated by electrophoresis on a $1.5 \%$ agarose gel with $1 \mathrm{X}$ Tris-acetate-EDTA buffer, stained with ethidium bromide, and visualized under ultraviolet light. PCR products of the expected size were collected using a DNA extraction kit (Omega), purified from the gel, and stored at $-20^{\circ} \mathrm{C}$.

\section{cDNA sequence cloning and identification}

PCR products were ligated into a pMD19-T vector for $12 \mathrm{~h}$ at $4^{\circ} \mathrm{C}$. The recombinant molecules were transformed into $E$. coli $\mathrm{DH} 5 \alpha$ competent cells, which were then spread on lysogeny broth plates containing $200 \mathrm{mg} / \mathrm{mL}$ isopropyl $\beta$-D-1-thiogalactopyranoside (IPTG), $50 \mu \mathrm{g} / \mathrm{mL}$ ampicillin, and $20 \mathrm{mg} / \mathrm{mL}$ X-gal. Plasmid DNA was isolated and digested by Pst and ScaII to verify the presence of inserts before being sequenced by Huada Zhongsheng Scientific Corporation (Beijing, China; Henry et al., 1993; Hou et al., 2007).

\section{Cloning the FTL genomic sequence}

The FTL-F and FTL-R primers mentioned above were used to amplify the genomic sequence of the FTL gene by touchdown PCR under the following conditions: $94^{\circ} \mathrm{C}$ for $30 \mathrm{~s}$, $62^{\circ} \mathrm{C}$ for $45 \mathrm{~s}$, and $72^{\circ} \mathrm{C}$ for $4 \mathrm{~min}$ in the first cycle, after which the annealing temperature was decreased by $0.5^{\circ} \mathrm{C}$ per cycle; after 20 cycles, the conditions were then kept as $94^{\circ} \mathrm{C}$ for 30 $\mathrm{s}, 52^{\circ} \mathrm{C}$ for $45 \mathrm{~s}$, and $72^{\circ} \mathrm{C}$ for $4 \mathrm{~min}$ for the next 20 cycles (Vaarala et al., 1998; Zhou et al., 2004). The amplified fragment was purified, ligated into the cloning vector, and transformed into E. coli competent cells. The recombinant fragment was then sequenced by Invitrogen (Shanghai, China; Wu et al., 2010).

\section{Expression vector construction and overexpression of recombinant FTL}

A PCR fragment encoding the FTL polypeptide was amplified from the cloned FTL cDNA. The forward and reverse primers used were 5'-ACGAATTCATGAGCTCCCAG-3' (underlined bases indicate an EcoRI restriction site) and 5'-GCAAGCTTCTAGTCGTGCTT TC-3' (HindIII), respectively. The PCR was performed as follows: $94^{\circ} \mathrm{C}$ for $3 \mathrm{~min}$, then 30 cycles of $94^{\circ} \mathrm{C}$ for $30 \mathrm{~s}, 53^{\circ} \mathrm{C}$ for $45 \mathrm{~s}$, and $72^{\circ} \mathrm{C}$ for $60 \mathrm{~s}$, before holding the reaction at $72^{\circ} \mathrm{C}$ for $10 \mathrm{~min}$. The amplified PCR product was cut and ligated into the corresponding site of the

Genetics and Molecular Research 15 (3): gmr.15038593 
pET28a vector (Stratagen). The resulting construct was transformed into E. coli cells of the BL21(DE3) strain (Novagen, Madison, WI, USA), in which its transcription was induced by adding $0.5 \mathrm{mM}$ IPTG at an $\mathrm{OD}_{600}$ of 0.6 , and culturing for up to $4 \mathrm{~h}$ at $37^{\circ} \mathrm{C}$. BL21(DE3) cells transformed with an empty vector were used as a control. Recombinant protein expression was assessed after $0,1,1.5,2,2.5,3$, and $4 \mathrm{~h}$ of induction. Proteins were stained with Coomassie blue R-250 and separated by SDS-polyacrylamide gel electrophoresis (PAGE; Cheng et al., 2002; Choveaux et al., 2012; Rodríguez and Hardy, 2015).

\section{Purification of the recombinant FTL protein}

Nickel chelate affinity chromatography can be used to isolate recombinant proteins with hexahistidine tags (His-tags). Sonicated sediment was centrifuged and suspended in Inclusion Body Binding Buffer on ice, until inclusion bodies were thoroughly dissolved. After further centrifugation, the supernatant was transferred to a nickel affinity chromatography column (Sigma-Aldrich, Shanghai, China). The column was washed with 15 times its volume of Inclusion Body Binding Buffer to flush out unbound proteins, and the outflowing liquid was collected. Inclusion Body Elution Buffer equal to five times the column volume was used to wash the bound protein. Then, according to the column volume, liquid containing the eluted protein was collected.

\section{Data analysis}

The open reading frame (ORF) of the DNA sequence was determined using ORF Finder (http://www.ncbi.nlm.nih.gov/gorf/gorf.html), while sequence data were analyzed with GENSCAN (http://genes.mit.edu/GENSCAN.html). A homology search comparing the FTL sequence of the giant panda to those of other species was performed using BLAST 2.1 (http:// www.ncbi.nlm.nih.gov/blast/). Molecular weight and isoelectric point (pI) were estimated using the Compute $\mathrm{pI} / \mathrm{Mw}$ tool (http://www.expasy.org/tools/pi_tool.html). Multiple-sequence alignment was carried out with DNASTAR Lasergene (DNAStar, NY, USA) and DNAMAN 6.0 (Lynnon Biosoft, NY, USA) softwares. The tertiary structure of the recombinant FTL protein was predicted by SWISS-MODEL (http://swiss-model.expasy.org/), while protein structure was inferred from the cloned FTL sequence using PredictProtein (http://cubic.Bioc. columbia.edu/predictprotein/).

\section{RESULTS}

\section{Analysis of giant panda $F T L$ cDNA}

A cDNA fragment of approximately $500 \mathrm{bp}$ was amplified from the giant panda tissue. The length of the cloned cDNA was $580 \mathrm{bp}$. On the basis of the high identity score obtained, we concluded that the cDNA isolated was that of the giant panda FTL sequence, which was submitted to GenBank under accession No. KJ526296. An ORF of 525 bp encoding 175 amino acids was identified (Figure 1). The $580 \mathrm{bp}$ of the giant panda FTL sequence was found to contain untranslated regions (UTRs) of 3 and $9 \mathrm{bp}$ at its 5'- and 3'-ends, respectively. Alignment of FTL sequences from the giant panda, $H$. sapiens, $B$. taurus, $C$. lupus familiaris, C. porcellus, E. caballus, M. fascicularis, O. cuniculus, S. scrofa, and F. catus indicated that 
both the nucleotide sequence and the deduced amino acid sequence are highly conserved. No deletions or insertions of nucleotide or amino acid residues were evident. BLAST analysis revealed that the FTL nucleotide sequence cloned from the giant panda demonstrates high levels of homology with those of C. lupus familiaris, F. catus, B. taurus, C. porcellus, and E. caballus, with values of 95.4, 93.7, 91.4, 90.3, and 90.3\%, respectively. Amino acid sequence homology with these five species was found to be $95.1,93.6,89.8,84.7$, and $90.5 \%$, respectively (Table 1$)$.

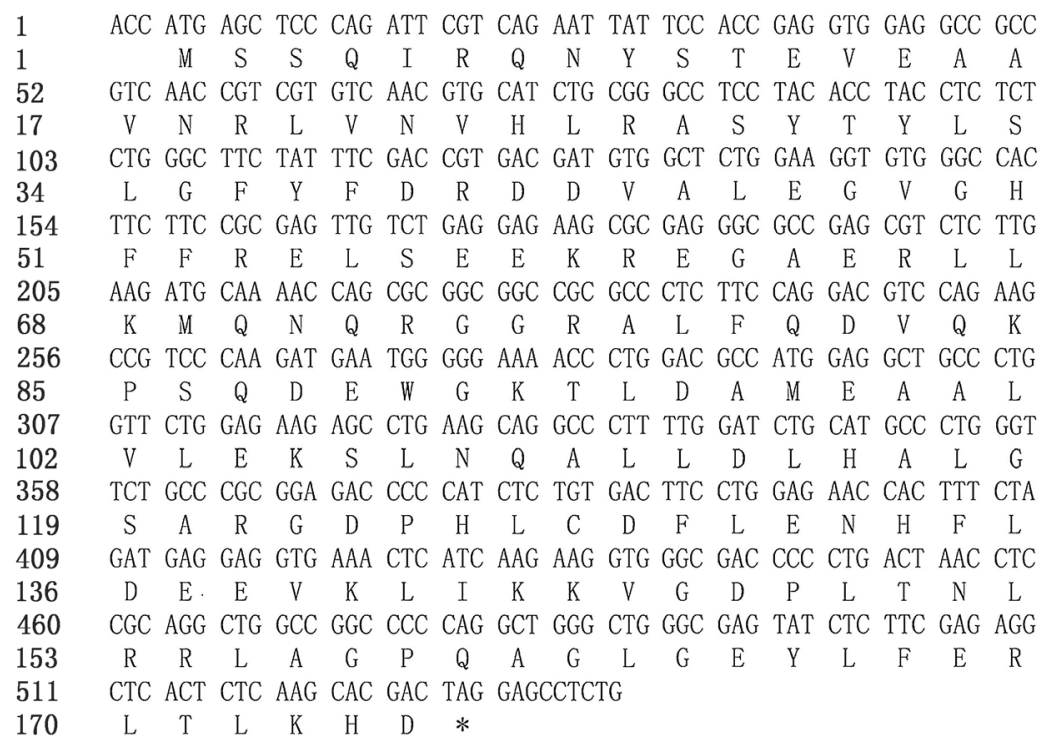

Figure 1. Nucleotide sequence of giant panda ferritin light polypeptide gene complementary DNA, and the amino acid sequence deduced from the open reading frame. Nucleotides are numbered from 5' to 3 '. Predicted amino acids are shown under nucleotides. The asterisk represents the termination codon.

Table 1. Comparison of ferritin light polypeptide nucleotide and amino acid sequences among 10 species (\%).

\begin{tabular}{|c|c|c|c|c|c|c|c|c|c|c|}
\hline & $\begin{array}{c}\text { Homo sapiens } \\
100 \%\end{array}$ & $\begin{array}{l}\text { Ailuropoda melanoleuca } \\
100 \%\end{array}$ & $\begin{array}{c}\begin{array}{c}\text { Bos taurus } \\
100 \%\end{array} \\
\end{array}$ & $\begin{array}{c}\text { Canis lupus familiaris } \\
100 \%\end{array}$ & $\begin{array}{c}\text { Cavia porcellus } \\
100 \%\end{array}$ & $\begin{array}{r}\text { Equus caballus } \\
100 \%\end{array}$ & $\begin{array}{c}\begin{array}{c}\text { Felis catus } \\
100 \%\end{array} \\
\end{array}$ & $\begin{array}{l}\text { Macaca fascicularis } \\
\quad 100 \%\end{array}$ & $\begin{array}{l}\text { Oryctolagus cuniculus } \\
100 \%\end{array}$ & $\begin{array}{c}\text { Sus scrofa } \\
100 \%\end{array}$ \\
\hline Homo sapiens $100 \%$ & & & & & & & & & & \\
\hline Ailuropoda melanoleuca $100 \%$ & 86.3 & & 89.8 & 95.1 & 84.7 & 90.5 & 93.6 & 87.9 & 87.9 & 88.6 \\
\hline Bos Taurus $100 \%$ & 84.0 & 91.4 & & 90.0 & 84.3 & 87.7 & 90.0 & 86.4 & 83.9 & 90.5 \\
\hline Canis lupus familiaris $100 \%$ & 86.9 & 95.4 & 92.6 & & 85.6 & 90.7 & 93.9 & 88.3 & 88.4 & 89.6 \\
\hline Cavia porcellus $100 \%$ & 85.1 & 90.3 & 88.0 & 90.3 & & 84.7 & 84.5 & 83.5 & 84.3 & 85.0 \\
\hline Equus caballus $100 \%$ & 87.4 & 90.3 & 86.3 & 90.9 & 86.3 & & 91.3 & 87.7 & 86.9 & 87.5 \\
\hline Felis catus $100 \%$ & 86.3 & 93.7 & 93.1 & 96.0 & 89.1 & 89.7 & & 87.3 & 87.5 & 88.4 \\
\hline Macacasa fascicularis $100 \%$ & 97.1 & 86.9 & 85.1 & 88.0 & 85.1 & 86.9 & 86.9 & & 85.4 & 86.4 \\
\hline Oryctolagus cuniculus $100 \%$ & 85.7 & 89.7 & 86.9 & 90.3 & 88.0 & 88.0 & 91.4 & 86.3 & & 85.4 \\
\hline Sus scrofa $100 \%$ & 86.3 & 90.3 & 88.6 & 92.0 & 86.9 & 86.9 & 92.0 & 86.9 & 88.0 & \\
\hline
\end{tabular}

Homology values relating to ferritin light polypeptide nucleotide and amino acid sequences are given above and below the diagonal, respectively.

\section{Giant panda $F T L$ genomic sequence analysis}

A fragment of approximately $1000 \mathrm{bp}$ was amplified from giant panda genomic DNA using primers FTL-F and FTL-R. The length of the cloned DNA fragment was 1065 bp. Comparison between the cDNA obtained and this DNA fragment revealed the former to 
be a full-length sequence, corresponding to four exons of the giant panda genomic FTL gene (Table 2). The genomic FTL sequence has also been submitted to GenBank, under accession No. KJ526296.

Table 2. Comparison of the ferritin light polypeptide genomic sequences of 10 vertebrate species.

\begin{tabular}{|c|c|c|c|c|c|c|c|}
\hline Species & Length (bp) & No. of exons & No. of introns & 5'-UTR & 3'-UTR & Join sites in the CDS & Accession No. \\
\hline Ailuropoda melanoleuca & 1065 & 4 & 3 & 3 & 9 & $4 . .105,271 . .417,663 . .788,904 . .1056$ & KJ526296 \\
\hline Homo sapiens & 1571 & 4 & 3 & 199 & 144 & $200 . .301,462 . .608,973 . .1098,1275 . .1427$ & NG_008152 \\
\hline Canis lupus familiaris & 1467 & 4 & 3 & 206 & 166 & $207.308,478 . .624,907 . .1032,1149 . .1301$ & NC_006583 \\
\hline Equus caballus & 931 & 3 & 2 & 0 & 0 & $1.135,494.619,780 . .931$ & NC_009153 \\
\hline Felis catus & 1211 & 4 & 3 & 0 & 126 & $1 . .102,273.419,691 . .816,933 . .1085$ & NC_018737 \\
\hline Cavia porcellus & 1305 & 4 & 3 & 116 & 156 & $117 . .218,380.526,740 . .865,997 . .1149$ & NT_176349 \\
\hline Bos taurus & 1835 & 4 & 3 & 190 & 154 & $191.292,459 . .605,1233.1358,1529 . .1681$ & NC_007316 \\
\hline Macaca fascicularis & 1971 & 4 & 3 & 278 & 128 & $279.380,542 . .688,1058.1183,1675 . .1827$ & NC_022290 \\
\hline Oryctolagus cuniculus & 1309 & 4 & 3 & 101 & 128 & $102 . .204,341 . .487,808 . .933,1029 . .1181$ & NW_003159655 \\
\hline Sus scrofa & 1637 & 4 & 3 & 251 & 158 & $252 . .353,520 . .666,1021 . .1146,1327 . .1479$ & NC_010448 \\
\hline
\end{tabular}

$\mathrm{UTR}=$ untranslated region, $\mathrm{CDS}=$ coding sequence.

\section{Prediction and analysis of functional sites in the giant panda FTL protein}

Primary structure analysis revealed the molecular weight of the putative giant panda FTL protein to be $19.90 \mathrm{kDa}$, with a theoretical $\mathrm{pI}$ of 5.53 (Table 3). Topology prediction identified one N-glycosylation site, two casein kinase II phosphorylation sites, one N-myristoylation site, two protein kinase $\mathrm{C}$ phosphorylation sites, and one cell attachment sequence (Figure 2). This striking pattern of similarity across evolutionary distance is understandable, given that FTL genes encode a group of highly conserved housekeeping proteins. Ten aligned sequences were used to generate a phylogenetic tree, in which A. melanoleuca formed a clade with $C$. lupus familiaris, and demonstrated very close genetic relationships with the other included species (Figure 3). Further analysis revealed a small number of polymorphic sites among the amino acid sequences of the 10 species being compared. However, most base substitutions within the protein-coding sequences were synonymous mutations.

Table 3. Molecular weights and isoelectric points of the ferritin light polypeptide from Ailuropoda melanoleuca
and 9 other vertebrate species.
\begin{tabular}{l|c|c|c}
\hline Species & Length (amino acids) & Molecular weight (kDa) & Isoelectric point \\
\hline Homo sapiens & 175 & 20.0 & 5.50 \\
\hline Canis lupus familiaris & 175 & 20.0 & 5.60 \\
\hline Equus caballus & 175 & 20.0 & 5.37 \\
\hline Cavia porcellus & 175 & 19.9 & 5.64 \\
\hline Felis catus & 175 & 20.1 & 5.51 \\
\hline Bos Taurus & 175 & 19.9 & 5.88 \\
\hline Macaca fascicularis & 175 & 20.0 & 5.36 \\
\hline Oryctolagus cuniculus & 175 & 20.0 & 5.69 \\
\hline Sus scrofa & 175 & 20.1 & 5.74 \\
\hline Ailuropoda melanoleuca & 175 & 19.9 & 5.53 \\
\hline
\end{tabular}

\section{FTL gene overexpression in $E$. coli and FTL protein purification}

The giant panda FTL gene was overexpressed in E. coli. The pET28a plasmids used included strong promoter and terminator sequences derived from phage T7. FTL was amplified specifically by PCR and cloned in a pET28a plasmid containing a sequence encoding an N-terminal His-tag extension. Expression was tested by SDS-PAGE analysis of protein 


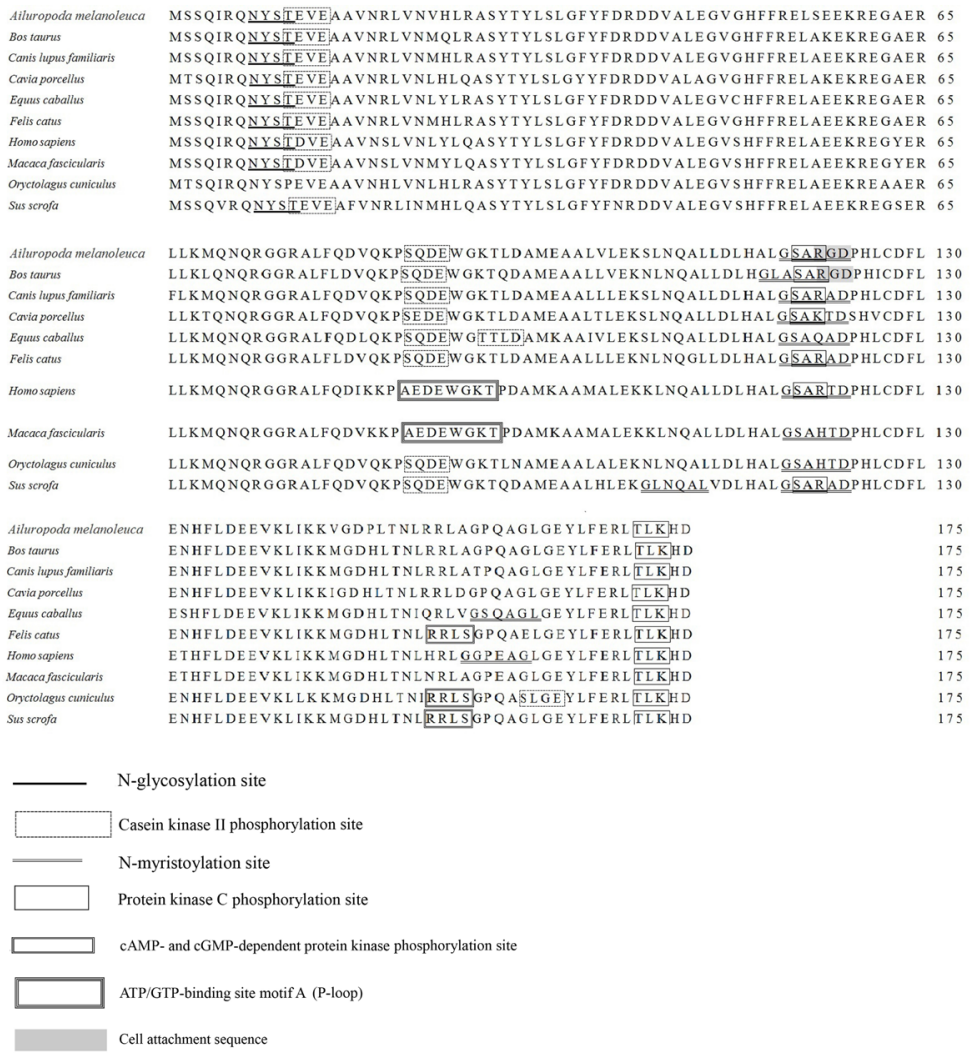

Figure 2. Comparison of ferritin light polypeptide amino acid sequences among various species.

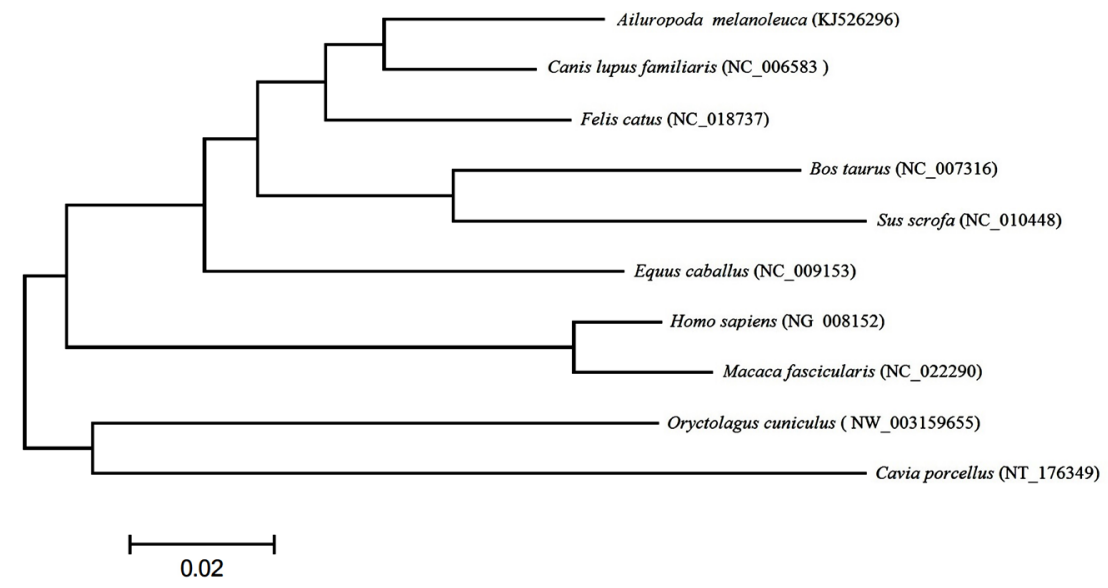

Figure 3. Maximum likelihood phylogenetic tree based on the open reading frame of the ferritin light polypeptide gene from a variety of species.

Genetics and Molecular Research 15 (3): gmr.15038593 
extracts from recombinant $E$. coli BL21(DE3) cells. Under optimized expression conditions, we obtained a large quantity of recombinant protein. SDS-PAGE analysis clearly indicated polypeptides of approximately $25.5 \mathrm{kDa}$ in lanes 9 of the gel (Figure 4). These results showed accumulation of the N-terminal His-tag FTL fusion protein of the expected size, which was also seen to form inclusion bodies. The recombinant protein was expressed after $30 \mathrm{~min}$ of induction and reached its highest level after $4 \mathrm{~h}$. These findings suggest that the protein expressed was only that encoded by the FTL gene of $A$. melanoleuca. The protein thus obtained could then be purified and its function studied further. Protein separation and purification are key steps in genetic engineering technology; therefore, we used affinity chromatography to purify the protein of interest. During this process, the protein solution $\mathrm{pH}$ was changed once, enabling us to achieve a high purity. Firstly, the solution was passed through the column under acidic conditions, then, the protein was eluted by changing the buffer $\mathrm{pH}$. The consistency in size of the purified and unpurified FTL suggests that this protein is the only such encoded by the giant panda FTL gene. The recombinant FTL protein acquired consisted of 190- amino acid residues, while its molecular weight was $25.51 \mathrm{kDa}$. The base changes identified did not result in any modifications to the encoded amino acid sequence of the expressed protein. Consequently, its structure was unaffected (Figure 5A and 5B).

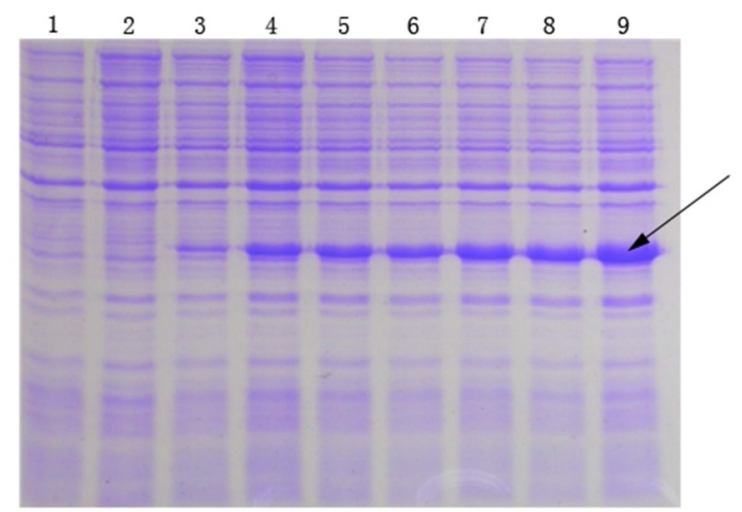

Figure 4. Protein extracted from recombinant Escherichia coli BL21(DE3) cells was analyzed by sodium dodecyl sulfate-polyacrylamide gel electrophoresis and stained with Coomassie blue R-250. The arrow indicates the recombinant protein bands observed after isopropyl $\beta$-D-1-thiogalactopyranoside treatment for $0,1,1.5,2,2.5,3$, and $4 \mathrm{~h}$ (lanes 3-9). Lanes 1 and 2 represent proteins extracted from $E$. coli cells transformed with empty vectors.

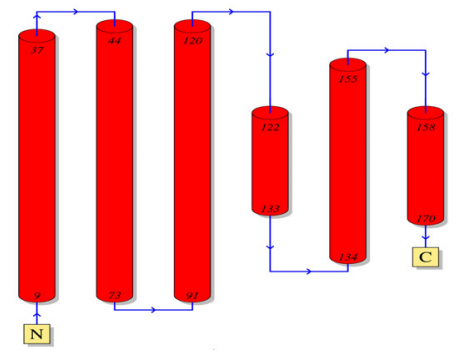

A

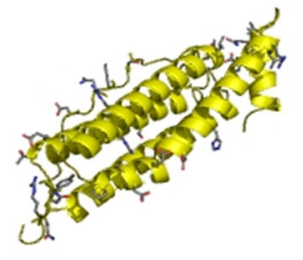

B

Figure 5. Secondary (A) and tertiary (B) structure of the giant panda recombinant ferritin light polypeptide. 


\section{DISCUSSION}

Alignment of $F T L$ sequences from H. sapiens, B. taurus, C. lupus familiaris, C. porcellus, E. caballus, M. fascicularis, O. cuniculus, S. scrofa, F. catus, and A. melanoleuca, and the giant panda indicated that the latter shares the highest nucleotide and amino acid sequence homology with C. lupus familiaris. Physical and chemical analysis showed that the putative molecular weight of the FTL protein and its theoretical pI were very similar among these ten mammals. Topology prediction revealed one $\mathrm{N}$-glycosylation site, two casein kinase II phosphorylation sites, one N-myristoylation site, two protein kinase $\mathrm{C}$ phosphorylation sites, and one cell attachment sequence in the FTL of the giant panda. However, additional functional sites were found to be present in this protein in other animals, including a cAMP- and cGMP-dependent protein kinase phosphorylation site and an ATP/GTP-binding site motif A (P-loop). It has been reported that ferritins form highly conserved three-dimensional structures resembling spherical shells. They can accommodate large amounts of iron in a safe, soluble, and bioavailable form. In vertebrates, cytosolic ferritins are composed of $\mathrm{L}$ and $\mathrm{H}$ subunits, which assemble in a tissue-specific ratio to flexibly adapt to the cell's needs. Hereditary hyperferritinemia-cataract syndrome is an autosomal dominant disorder (Arosio et al., 2009) causing juvenile-onset cataracts and elevated serum ferritin levels. It is caused by a mutation in the iron response element within the 5'-UTR of the FTL gene, which leads to uncontrolled expression of L-ferritin (Levi et al., 2005). Our study found that even compared with $F$. catus, functional sites within the giant panda FTL protein are considerably different. In the giant panda protein, the 122nd amino acid is a Gly, resulting in a cell attachment sequence, while in other species, a $\mathrm{T}$ or A residue is found in this position. However, the substitution of one of the amino acids at positions 153-156 (RRLA) of the giant panda FTL sequence has led to the disappearance of a cAMP- and cGMP-dependent protein kinase phosphorylation site. In addition, residues 156-162 of the giant panda FTL consist of the sequence AGPQAGL, in contrast to other mammals, for which sequences such as VGSQAGL and GGPEAGL are found in this region. This change leads to the loss of an N-myristoylation site in the giant panda protein. Most importantly, FTL proteins from H. sapiens and M. fascicular contain an ATP/GTP-binding site motif A (P-loop). This indicates that FTL may perform varied functions in different species. For example, ferritin may take on different architectures, with 12 or 24 equivalent or non-equivalent subunits, all surrounding a large cavity. All ferritins readily interact with $\mathrm{Fe}(\mathrm{II})$ to induce its oxidation, which is catalyzed by the ferroxidase center of this cavity. Ferritin expression is also regulated by iron and oxidative damage, and in vertebrates, it plays a central role in the control of cellular iron homeostasis (Cao et al., 2010). The phylogenetic tree based on FTL gene sequences from 10 species exhibited high support values for each branch and was consistent with traditional taxonomic findings, successfully revealing the evolutionary relationships among these organisms. All such data relating to the FTL gene and its protein product have potential value in giant panda taxonomy and phylogenetic comparisons.

\section{Conflicts of interest}

The authors declare no conflict of interest.

\section{ACKNOWLEDGMENTS}

Research supported by the National Natural Science Foundation of China (\#31400016

Genetics and Molecular Research 15 (3): gmr.15038593 
and \#31200012), the Youth Project of Zhanjiang Normal University (\#QL1116), the Science and Technology Support Project of Sichuan Province (\#2014SZ0020 and \#2014FZ0024), the Cultivate Major Projects of Sichuan Province (\#14CZ0016), the Open Foundation of Microbial Resources and Drug Development of Key Laboratory of Guizhou Province (\#GZMRD-2014-002), and the Doctor Startup Foundation Project of China West Normal University (\#11B019 and \#11B020).

\section{REFERENCES}

Allerson CR, Cazzola M and Rouault TA (1999). Clinical severity and thermodynamic effects of iron-responsive element mutations in hereditary hyperferritinemia-cataract syndrome. J. Biol. Chem. 274: 26439-26447. http://dx.doi. org/10.1074/jbc.274.37.26439

Álvarez-Coca-González J, Moreno-Carralero MI, Martínez-Pérez J, Méndez M, et al. (2010). The hereditary hyperferritinemia-cataract syndrome: a family study. Eur. J. Pediatr. 169: 1553-1555. http://dx.doi.org/10.1007/ $\underline{\text { s00431-010-1251-2 }}$

Arosio P, Ingrassia R and Cavadini P (2009). Ferritins: a family of molecules for iron storage, antioxidation and more. Biochim. Biophys. Acta 1790: 589-599. http://dx.doi.org/10.1016/j.bbagen.2008.09.004

Cao W, McMahon M, Wang B, O'Connor R, et al. (2010). A case report of spontaneous mutation (C33>U) in the ironresponsive element of L-ferritin causing hyperferritinemia-cataract syndrome. Blood Cells Mol. Dis. 44: $22-27$. $\underline{\text { http://dx.doi.org/10.1016/j.bcmd.2009.09.003 }}$

Cazzola M, Bergamaschi G, Tonon L, Arbustini E, et al. (1997). Hereditary hyperferritinemia-cataract syndrome: relationship between phenotypes and specific mutations in the iron-responsive element of ferritin light-chain mRNA. Blood 90: 814-821.

Cheepsunthorn P, Palmer C and Connor JR (1998). Cellular distribution of ferritin subunits in postnatal rat brain. J. Comp. Neurol. 400: 73-86. http://dx.doi.org/10.1002/(SICI)1096-9861(19981012)400:1<73::AID-CNE5>3.0.CO;2-Q

Cheng Q, Lau WM, Chew SH, Ho TH, et al. (2002). Identification of molecular markers for the early detection of human squamous cell carcinoma of the uterine cervix. Br. J. Cancer 86: 274-281. http://dx.doi.org/10.1038/sj.bjc.6600038

Choveaux D, Krause RG and Goldring JP (2012). Rapid detection of proteins in polyacrylamide electrophoresis gels with Direct Red 81 and Amido Black. Methods Mol. Biol. 869: 585-589. http://dx.doi.org/10.1007/978-1-61779-821-4_53

Connor JR, Menzies SL, Burdo JR and Boyer PJ (2001). Iron and iron management proteins in neurobiology. Pediatr. Neurol. 25: 118-129. http://dx.doi.org/10.1016/S0887-8994(01)00303-4

Du YJ, Luo XY, Hao YZ, Zhang T, et al. (2007). cDNA cloning and overexpression of acidic ribosomal phosphoprotein P1 gene (RPLP1) from the giant panda. Int. J. Biol. Sci. 3: 428-433. http://dx.doi.org/10.7150/1jbs.3.428

Ferreira C, Bucchini D, Martin ME, Levi S, et al. (2000). Early embryonic lethality of H ferritin gene deletion in mice. $J$. Biol. Chem. 275: 3021-3024. http://dx.doi.org/10.1074/jbc.275.5.3021

Goto F, Yoshihara T, Shigemoto N, Toki S, et al. (1999). Iron fortification of rice seed by the soybean ferritin gene. Nat. Biotechnol. 17: 282-286. http://dx.doi.org/10.1038/7029

Henry JL, Coggin DL and King CR (1993). High-level expression of the ribosomal protein L19 in human breast tumors that overexpress erbB-2. Cancer Res. 53: 1403-1408.

Hou WR, Du YJ, Chen Y, Wu X, et al. (2007). Nucleotide sequence of cDNA encoding the mitochondrial precursor protein of the ATPase inhibitor from the giant panda (Ailuropoda melanoleuca). DNA Cell Biol. 26: 799-802. http:// dx.doi.org/10.1089/dna.2007.0626

Hou WR, Hou YL, Ding X and Wang T (2012). cDNA, genomic sequence cloning and overexpression of giant panda (Ailuropoda melanoleuca) mitochondrial ATP synthase ATP5G1. Genet. Mol. Res. 11: 3164-3174. http://dx.doi. org/10.4238/2012.September.3.5

Hou YL, Ding X, Hou W, Song B, et al. (2013). Overexpression, purification, and pharmacologic evaluation of anticancer activity of ribosomal protein L24 from the giant panda (Ailuropoda melanoleuca). Genet. Mol. Res. 12: 4735-4750. http://dx.doi.org/10.4238/2013.October.18.11

Levi S, Cozzi A and Arosio P (2005). Neuroferritinopathy: a neurodegenerative disorder associated with L-ferritin mutation. Best Pract. Res. Clin. Haematol. 18: 265-276. http://dx.doi.org/10.1016/j.beha.2004.08.021

Liao MJ, Zhu MY, Zheng X, Zhang ZH, et al. (2003). cDNA cloning of growth hormone from giant panda (Ailuropoda melanoleuca) and its expression in Escherichia coli. Comp. Biochem. Physiol. B Biochem. Mol. Biol. 135: $109-116$.

McLeod JL, Craig J, Gumley S, Roberts S, et al. (2002). Mutation spectrum in Australian pedigrees with hereditary

Genetics and Molecular Research 15 (3): gmr.15038593 
hyperferritinaemia-cataract syndrome reveals novel and de novo mutations. Br. J. Haematol. 118: 1179-1182. http:// dx.doi.org/10.1046/j.1365-2141.2002.03690.x

Nutting CM, Robinson M and Birchall M (2008). Survival from laryngeal cancer in England and Wales up to 2001. Br. J. Cancer 99 (Suppl 1): S38-S39. http://dx.doi.org/10.1038/sj.bjc.6604582

Park KS, Kim H, Kim NG, Cho SY, et al. (2002). Proteomic analysis and molecular characterization of tissue ferritin light chain in hepatocellular carcinoma. Hepatology 35: 1459-1466. http://dx.doi.org/10.1053/jhep.2002.33204

Ricolleau G, Charbonnel C, Lodé L, Loussouarn D, et al. (2006). Surface-enhanced laser desorption/ionization time of flight mass spectrometry protein profiling identifies ubiquitin and ferritin light chain as prognostic biomarkers in node-negative breast cancer tumors. Proteomics 6: 1963-1975. http://dx.doi.org/10.1002/pmic.200500283

Rodríguez C and Hardy E (2015). Lipopolysaccharide aggregates in native agarose gels detected by reversible negative staining with imidazole and zinc salts. Anal. Biochem. 485: 72-80. http://dx.doi.org/10.1016/j.ab.2015.06.020

Salvador GA (2010). Iron in neuronal function and dysfunction. Biofactors 36: 103-110. http://dx.doi.org/10.1002/biof.80

Stites SW, Plautz MW, Bailey K, O’Brien-Ladner AR, et al. (1999). Increased concentrations of iron and isoferritins in the lower respiratory tract of patients with stable cystic fibrosis. Am. J. Respir. Crit. Care Med. 160: 796-801. http:// dx.doi.org/10.1164/ajrccm.160.3.9811018

Tolar J and Neglia JP (2003). Transplacental and other routes of cancer transmission between individuals. J. Pediatr. Hematol. Oncol. 25: 430-434. http://dx.doi.org/10.1097/00043426-200306000-00002

Vaarala MH, Porvari KS, Kyllönen AP, Mustonen MV, et al. (1998). Several genes encoding ribosomal proteins are overexpressed in prostate-cancer cell lines: confirmation of L7a and L37 over-expression in prostate-cancer tissue samples. Int. J. Cancer 78: 27-32. http://dx.doi.org/10.1002/(SICI)1097-0215(19980925)78:1<27::AID-IJC6>3.0.CO;2-Z

Wang CD, Long K, Jin L, Huang S, et al. (2015). Identification of conserved microRNAs in peripheral blood from giant panda: expression of mammary gland-related microRNAs during late pregnancy and early lactation. Genet. Mol. Res. 14: 14216-14228. http://dx.doi.org/10.4238/2015.November.13.5

Wang ZQ, Wang W, Shi L, Chai JT, et al. (2016). Molecular cloning and pharmacological characterization of giant panda (Ailuropoda melanoleuca) melanocortin-4 receptor. Gen. Comp. Endocrinol. 229: 32-40. http://dx.doi.org/10.1016/j. ygcen.2016.02.016

Wu GF, Hou YL, Hou WR, Song Y, et al. (2010). Giant panda ribosomal protein S14: cDNA, genomic sequence cloning, sequence analysis, and overexpression. Genet. Mol. Res. 9: 2004-2015. http://dx.doi.org/10.4238/vol9-4gmr899

Zhang Y, Zhang R, Zou J, Hu X, et al. (2013). Identification and characterization of four ferritin subunits involved in immune defense of the Yesso scallop (Patinopecten yessoensis). Fish Shellfish Immunol. 34: 1178-1187. http:// dx.doi.org/10.1016/j.fsi.2013.01.023

Zhou J, Callapina M, Goodall GJ and Brüne B (2004). Functional integrity of nuclear factor kappaB, phosphatidylinositol 3'-kinase, and mitogen-activated protein kinase signaling allows tumor necrosis factor alpha-evoked Bcl-2 expression to provoke internal ribosome entry site-dependent translation of hypoxia-inducible factor 1alpha. Cancer Res. 64: 9041-9048. http://dx.doi.org/10.1158/0008-5472.CAN-04-1437

Genetics and Molecular Research 15 (3): gmr.15038593 